\title{
Epidemiology of Hepatitis B Virus (HBV) infection in TDPs of war against terrorism in North Waziristan, Pakistan
}

\author{
Muhammad Goher Zaman ${ }^{1}$, Zia Ur Rahman Awan ${ }^{1 *}$ and Mehboob Ur \\ Rahman Awan ${ }^{2}$ \\ 1. Department of Zoology, Government Post -Graduate College Bannu-Pakistan \\ 2. MTI District Head Quarter Teaching Hospital Bannu-Pakistan \\ *Corresponding author's email: Ziabiotech78@yahoo.com \\ Citation \\ Muhammad Goher Zaman, Zia Ur Rahman Awan and Mehboob Ur Rahman Awan. Epidemiology of Hepatitis \\ B Virus (HBV) infection in TDPS of war against terrorism in North Waziristan, Pakistan. Pure and Applied \\ Biology. Vol. 8, Issue 4, pp2187-2192. http://dx.doi.org/10.19045/bspab.2019.80164
}

\begin{tabular}{|c|c|c|c|}
\hline Received: 15/05/2019 & Revised: 14/07/2019 & Accepted: 22/07/2019 & Online First: 03/08/2019 \\
\hline
\end{tabular}

\section{Abstract}

Hepatitis B virus is the major cause of liver infection that includes hepatocellular carcinoma and liver cirrhosis. Globally 350 million peoples have been suffered from chronic infection of Hepatitis B Virus. The current study was conducted with the main aim to determine the epidemiology of hepatitis B virus in Temporary Displaced Persons (TDPs) during army operation against terrorism in North Waziristan. Blood samples from 1837 TDPs were collected that were migrated to District Bannu. Blood samples were collected from both sexes (male \& Female) having age range from 1- 60 years. All the collected blood samples were first diagnosed with ICT method and then with ELISA method at the study places during the mentioned period. The assessed variables included gender, age and risk factors. Out of 1837 samples, 237 (12.90\%) were found positive for HBsAg and were declaredpositive while the remaining $1600(87.09 \%)$ were found negative. The collected samples were all processed through ELISA in which 249 (13.55\%) samples were found to be positive for HBsAg while $1588(86.44 \%)$ were found negative. Males $(14.70 \%)$ were found to be more infected than females $(11.67 \%)$ and similarly, high rate of infection (28\%) was found in the old age peoples. HBV has been reported in the TDPs and population of the host district is at high risk. Diagnosis through ELISA is more accurate and sensitive than ICT method. Further proper screening and molecular diagnosis is needed in the area to control the dreadful disease.

Keywords: Bannu; ELISA; HBV; ICT; TDPs

\section{Introduction}

$\mathrm{HBV}$ is a member of Hepadnaviridae family, containing DNA viruses found in both mammals (Genus Orthohepadnavirus) and in birds (Genus Avihepadnaviruses) [1]. Australian antigen (AuAg) was $1^{\text {st }}$ time discovered by Brauch Blumberg in 1963 that was the antigen of hepatitis B virus, now known as Hepatitis B virus surface antigen (HBsAg). This antigen was discovered in the old Australian peoples known as Aboriginal Australians [2]. Worldwideabout three hundred and fifty (350) million of the total population suffer from chronic infection and two billion people are infected from a virus of family Hepadnaviridae [3].

HBV is the smallest circular virus of about $42 \mathrm{~nm}$ size and having Dane particle of $28 \mathrm{~nm}$ and tubular form of about $42 \mathrm{~nm}$. This circular virus is enveloped through secretary transport mechanism via Golgi 
apparatus and endoplasmic reticulum [4]. The virus also contains partially small double stranded DNA genome of $3.2 \mathrm{~kb}$ in length and contains 4 genes or open reading frames (ORF).Hepatitis b virus also causes hepatocellular carcinoma that is liver cancer and inflammation of liver cells [5]. There is several species of mammals like wood chucks (Marmota monax), in ground squirrels as well as in ducks these all can infected with non-human hepatitis $b$ virus and also cause acute and chronic hepatocellular carcinoma. The human HBV is distinguished from other primates HBV through nucleotide sequences of genome and also through the selected amino acids changes in viral protein [6]. Hepatitis B virus is externally enveloped and contains surface proteins that is HBsAg it play a major role in attachment with cell membrane to initiate infection in the form of inflammation of liver cells and liver cancer. Beneath the envelope there is viral capsid protein called as $\mathrm{HBcAg}$, this protein is made up from 183 or 185 amino acids depending on the genotype of virus $\mathrm{HBeAg}$ is another protein antigen in the infected blood that also show that virus is remain show replication and active [7]. This anti-gene is also called as endogenous core anti-gene, this anti-gene is prepared by the gene $\mathrm{C}$ which is also codified for the $\mathrm{HBcAg}$ [8]. HBeAg is a non-particular secretary protein discovered by Magnius and Epmark in 1972, during after preparing of protein from pre-core gene than this protein are sent to endoplasmic reticulum and Golgi complex for processing. After processing they secreted to the serum, the function of this antigen is unsolved [7]. $\mathrm{HBV}$ infection is a global problem that may progress towards acute, fulminant or chronic hepatitis, hepato-cellular carcinoma and cirrhosis of the liver. About two billion of the global population have been infected and similarly, 350 million are infected chronically. There is $25 \%$ risk of mortality related to sequelae of hepatitis $B$, approximately 1 million deaths per year. There are 8 genotypes of $\mathrm{HBV}$ from $\mathrm{A}$ to $\mathrm{H}$ on the basis of intra group nucleotide divergence of up to $4.2 \%$ of the $S$ genome sequences or in $>8 \%$ of the entire genome sequences which contains about 3200 base pairs [9]. These eight genotypes are present throughout the world having distinct geographical distribution patterns. Genotype A is reported in North West Europe, North America Philippines, and Hong Kong similarly Genotype $\mathrm{B}$ and $\mathrm{C}$ are found in the Southeast Asia. Genotype B is found extensively and reported throughout the world while Genotype $\mathrm{E}$ is found in the West and South Africa, Genotype F is distributed in central and south America. Genotype $\mathrm{G}$ is only found in the USA and France [5]. In serum or plasma, the HBsAg presence is a sign of hepatitis $B$ active infection; chronic or acute [10]. In view of the above genuine facts and limited data availability, the current study was designed to investigate the presence of $\mathrm{HBV}$ infection in TDPs settled in the District Bannu.

\section{Materials and methods}

From all the TDPs, settled in various regions of District Bannu, data was collected in the form of blood samples. Predesigned proforma including information of the individual was collected from all the individuals of the study. The study was evaluated and approved by Ethical committee of the institution. The ages of individuals included in the study, were in range of 1 to 70 years of age.

A $3 \mathrm{ml}$ sample of blood was collected from each individual in a tube. Sera were separated from the respective blood samples through centrifugation at $5000 \mathrm{rpm}$ for 10 minutes. The sera was separated and screened for presence of HBsAg by ICT (Accurate Diagnostics USA) according to the manufacturer's instructionsin the Biotechnology and Microbiology laboratory of Zoology department, Government Post-Graduate College Bannu. The samples were further screened by ELISA. HBsAg Sandwich ELISA kits of (Antec UK) were used for screening of all samples. 
All the data was entered and analyzed by using the Microsoft Office Excel program. Results were expressed in percentages (\%).

\section{Results}

Total 1837 TDPs including males and females of different ages were examined. Males were $1115(60.69 \%)$ and females were $722(39.30 \%)$ as given in (Table 1). The first screening was performed with ICT (Rapid diagnostic test) to find out the prevalence of HBsAg among TDPs while for further analysis ELISA techniques was performed to find out an actual prevalence of HBV infection among TDPs. Initial screening of the samples by ICT showed that $237(12.90 \%)$ individuals were positive while 1600(87.09\%) were negative for HBsAg. The ELISA results for all the screened individuals for HBsAg antibodies detection shows that $249(13.55 \%)$ subjects were positive and $1588(86.44 \%)$ were found negative (Table 2).

Similarly, various types of risk factors were also observed among the total screened individuals. Of the total observed risk factors, dental risk $(20.48 \%)$ was observed very frequently, followed by drugs addict $(16.06 \%)$, tattooing $(11.65 \%)$, re-use of syringes $(6.3 \%)$, contaminated blades $(4.81 \%)$, blood transfusion $(3.21 \%)$ and general surgery $(2.08 \%)$ (Table 3$)$.

Table 1. Sex wise Prevalence of the infection by ELISA among TDPs

\begin{tabular}{|c|c|c|c|c|c|}
\hline $\begin{array}{c}\text { Age } \\
\text { (years) }\end{array}$ & $\begin{array}{c}\text { Number } \\
\text { Screened }\end{array}$ & +ve & \%age & -ve & \%age \\
\hline $1-15$ & 421 & 11 & 2.67 & 410 & 97.38 \\
\hline $16-30$ & 513 & 57 & 11.11 & 456 & 88.88 \\
\hline $31-45$ & 433 & 79 & 18.24 & 354 & 81.75 \\
\hline $46-60$ & 445 & 95 & 21.34 & 350 & 78.65 \\
\hline$>60$ & 25 & 7 & 28 & 18 & 72 \\
\hline
\end{tabular}

Table 2. Prevalence of HBV infection by ELISA

\begin{tabular}{|c|c|c|c|c|c|}
\hline Sex & $\begin{array}{c}\text { Number of } \\
\text { samples }\end{array}$ & HBsAg +ve & $\begin{array}{c}\text { Prevalence } \\
\text { \%age }\end{array}$ & HBsAg -ve & $\begin{array}{c}\text { Prevalence } \\
\text { \%age }\end{array}$ \\
\hline Males & 1115 & 164 & 14.70 & 951 & 85.29 \\
\hline Females & 722 & 85 & 11.67 & 637 & 88.22 \\
\hline Total & $\mathbf{1 8 3 7}$ & $\mathbf{2 4 9}$ & $\mathbf{1 3 . 5 5}$ & $\mathbf{1 5 8 8}$ & $\mathbf{8 6 . 4 4}$ \\
\hline
\end{tabular}

Table 3. Risk factors for HBV infection observed among TDPs

\begin{tabular}{|c|c|c|}
\hline Risk factor & Observed cases & \%age \\
\hline Dental & 51 & 20.48 \\
\hline Drugs addict & 40 & 16.06 \\
\hline Tattooing & 29 & 11.65 \\
\hline Re-use syringes & 19 & 6.3 \\
\hline Contaminated blades & 12 & 4.81 \\
\hline Blood transfusion & 8 & 3.21 \\
\hline General surgery & 5 & 2.08 \\
\hline
\end{tabular}




\section{Discussion}

In Asia, South Europe, Latin America and Africa especially, hepatitis B virus infection is major health problem throughout the world. Approximately, 50 million people pass this disease every year [11]. Hepatitis B infection in different big cities of Pakistan is quite different, in Karachi 63\% and Peshawar 32\% [12].
In the present work, general population of TDPs was taken for research study in various regions of District Bannu. Their blood samples were diagnosed with ICT and ELISA methods. The comparative analysis shows that the ELISA technique is more sensitive than the ICT method because of high sensitivity for detection of HBsAg small quantity in the serum (Fig. 1).

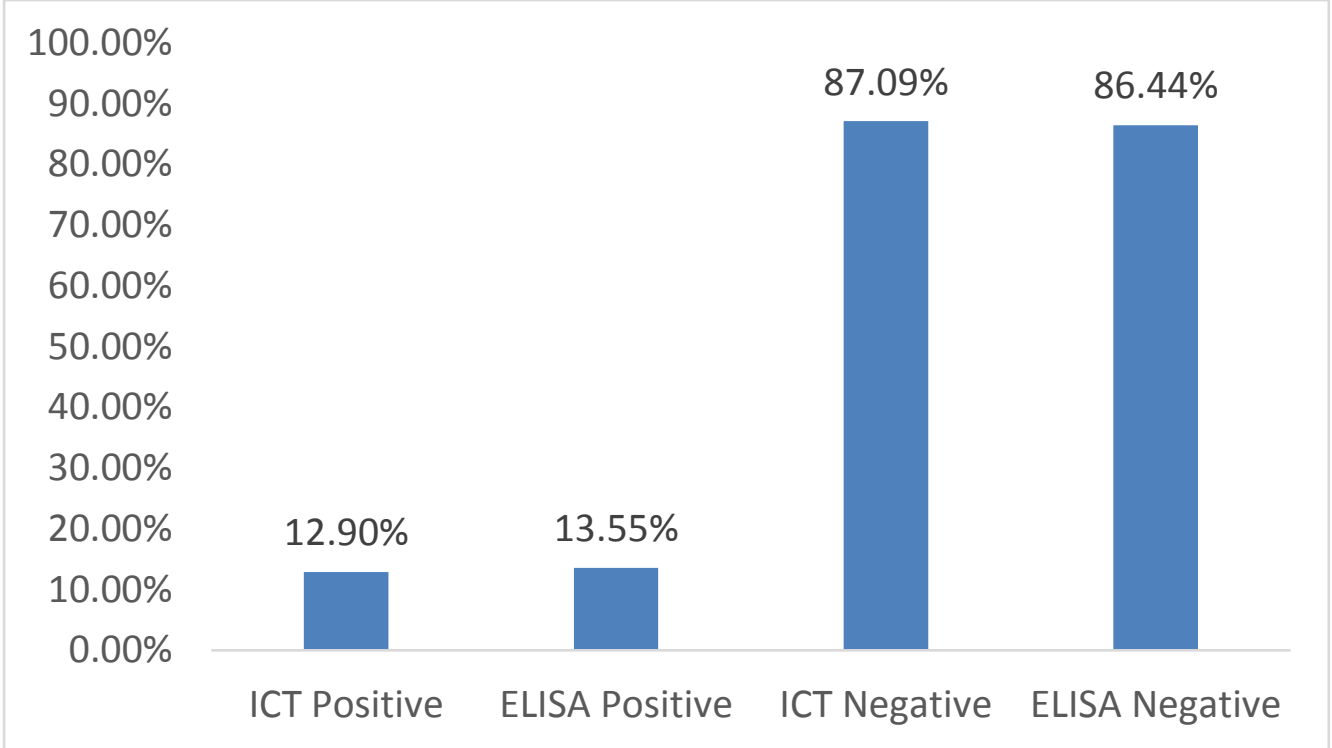

Figure 1. Comparative analysis of ICT and ELISA methods

The prevalence of infection was found high among TDPs especially in those having age range from 46 year to 60 years. This is due to the reason that in old age the immunity becomes weak and man becomes less careful about his health as a result infection rate increases. The highest risk factor is dental that is about $20.48 \%$ because viral infection is transmitted from patient to patient, dentist to patient or vice versa [13]. The second highest risk factor is drugs addicts that is $16.06 \%$ supported by relevant study in Pakistan [14]. The rate of infection in males was found more than in females [15]. Results of the current study matched and in line with other relevant studies, $[16,10]$ in which the rate of HBV infection is more in male than female. Some previous studies from Pakistan also supported the high rate of HBV infection in males as compared to females [17, 18]. Similar results of high prevalence rate of
HBV in male $(67.86 \%)$ were also observed in Bangladesh [19]. The reason for greater rate of infection in male than female may be the various risk behaviors in males. Highest rate of infection in males then females is due to their social responsibilities because according to the culture of North Waziristan male is everything of family therefore male will be at risk of HBV infection mostly. Males do their jobs as well as business, barber contact, blood and organ donation and drug abuse also.The most important reason due to which rate of infection is very high in the IDPs is lack of education. Major population of TDPs is uneducated as a result of which they have no any knowledge about HBV infection and about its risk factors [20]. The overall high rate of HBV infection in the study area may be due to the low economic status and unhygienic conditions [10]. North Waziristan agency is backward area there is no any 
advance health facilities that are available for peoples and no any proper education system is for the awareness of people about such viral infections. During war, Government of Pakistan gave them special response in the form of free medical treatment and awareness about such type of infections.

\section{Conclusion}

The HBV infection is present in a very high rate in TDPs of North Waziristan Agency. Due to direct contacts with local population of District Bannu KPK, the infection is transmitted from TDPs to local population, as a result, a huge viral prevalence will be occurred and a lot of population will be suffered. Proper molecular screening and effective steps on both medical and education level needs to control the disease.

\section{Authors' contributions}

Conceived and designed the experiments: MG Zaman \& ZUR Awan, Performed the experiments: MG Zaman, Analyzed the data: ZUR Awan \& MUR Awan, Contributed materials/ analysis/ tools: ZUR Awan \& MUR Awan, Wrote the paper: ZUR Awan \& MG Zaman.

\section{References}

1. Schaefer S (2007). Hepatitis B virus taxonomy and hepatitis B virus genotypes. 2007. World $J$ of Gastroenterol 13(1): 14-21.

2. Mackay IR (2008). Historical reflections on autoimmune hepatitis. World J Gastroenterol 14(21): 32923300 .

3. Lavanya V, Viswanathan T, Malar SS, Malarvizhi A \& Moorthy K (2008). Prevalence of hepatitis $\mathrm{B}$ virus infection among blood donors with antibodies to hepatitis B core antigen. Int J of Medicine and Med Sci 4(6): 128-137.

4. Saeed U, Waheed $\mathrm{Y}$ \& Ashraf $\mathrm{M}$ (2014). Hepatitis B and hepatitis C viruses review of viral genomes, viral induced host immune responses, genotypic distributions and worldwide epidemiology. Asian pac J Trop DIS 4(2): 88-96.
5. Awan AR, Babar ME, Ali A, Awan Z, Saleem Z \& Zahoor Y (2011). Phlogenetics and Evolution Association of Hepatitis B virus isolated from Pakistan. Pak J of Zool 43(1): 155-160.

6. Pujol FH, Cristina M, Hainaut P \& Chemin I (2009). Laboratoria de virologia molecular, CMBC, IVIC, Apdo 20632, Caracas 1020AVenezuela.

7. Jayalakshmi MK, Kalyanaraman N \& Chappan R (2013). Hepatitis B virus genetic diversity. Disease Pathogenesis. Licensee in Tech.

8. Aparicio RMR, Valdez-Salazar HA, Ozores GA \& Tachiquin MER (2014). Serotypes and Genotypes of the Hepatitis B virus in Latin America. Annual Res and Rev in Biol 4(8):13071318.

9. Attaullah S, Rehman SU, Khan S, Ali I, Ali S \& Khan SN (2011). Prevalence of hepatitis B virus genotypes in HBsAg positive individuals of Afghanistan. Virol J 8: 281.

10. Khan F, Akbar H, Idrees M, Khan H, Shahzad Khan \&Kayani MA (2011). The prevalence of HBV infection in the cohort of IDPs of war against terrorism in Malakand Division of Northern Pakistan. BMC Infect Dis 11: 176.

11. Ujjan ID, Aurangzeb M, Memmon RA, Memmon Rahman \& Memmon ZY (2012). Prevalence of hepatitis B virus (HBV) in association of Hepatitis Delta virus (HDV). Quarterly Med Channel MC 18(4): 53-57.

12. Attique MUH, Yousaf M, Haleem A \& Hassan A (1990). Prevalence of Hepatitis B virus in liver diseases in Bahawalpur. J of Postgraduate Med Institute 4(1).

13. Mehboobi N, Porter SR, Karayiannis $P$ \& Alavian SM (2013). Dental treatment as a risk factor for Hepatitis $\mathrm{B}$ and $\mathrm{C}$ viral infection. A review of the recent literature. J Gastrointestin Liver Dis 22(1): 79-86. 
14. Mansha I, Goher T, Zaka Muhammad \& Amin F (2012). Drug addiction and Hepatitis B and Cin Pakistan. Gomal J of Med Sci10 (2).

15. Ali A. Nisar M, Idress M, Ahmad M, Hussain A, Rafique S, Sabri S, Rehman H, Ali L, Wazir S \& Khan T (2012). Prevalence of HBV infection in suspected population of conflictaffected areas of war against terrorism in North Waziristan FATA Pakistan. Infection Genetics and Evolution 12: 1865-1869.

16. Naz $\mathrm{S}$, Ahmad Muhammad \&Asghar $\mathrm{H}$ (2002). Prevalence of Hepatitis 'B' Among Combined Military Hospital (CMH) Muzaffarabad. Int J Agric Biol 4: 227-230.

17. Alam MM, Zaidi SZ, Malik SA, Shaukat S, Naeem A, Sharif S, Angez Muhammad \& Butt JA (2007).
Molecular epidemiology of Hepatitis B virus genotypes in Pakistan. $B M C$ Infect Dis 7: 115.

18. Usman HR, Akhtar S, Rahbaqr MH, Hamid S, MoattarT \& Luby SP (2003). Injection in health care settings: A risk factor for acute hepatitis B virus infection in Karachi, Pakistan. $J$ Epidemol Infect 130: 293-300.

19. Mahtab M, Rahman S, Karim , Khan M, Foster G, Solaiman S \& Afroz S (2008). Epidemiology of hepatitis B virus in Bangladeshi general population. Hepatobiliary Pancreat Dis Int 7: 595-600.

20. Leung CM, Wong WH, Chan KH, Lai SW L, Luk YW, Lai JY, Yeung YW \& Hui,WH (2010). Public awareness of hepatitis B infection:a population based telephone survey in Hong Kong. Hong Kong Med J 16: 463-9. 